University of New Hampshire

University of New Hampshire Scholars' Repository

Sociology Scholarship

Sociology

8-1-2016

\title{
Wildfire, climate, and perceptions in northeast Oregon
}

Lawrence C. Hamilton

University of New Hampshire, Durham, lawrence.hamilton@unh.edu

Joel N. Hartter

University of New Hampshire, Durham, joel.hartter@unh.edu

Barry D. Keim

Louisiana State University

Angela E. Boag

University of Colorado

Michael W. Palace

University of New Hampshire, Durham, michael.palace@unh.edu

See next page for additional authors

Follow this and additional works at: https://scholars.unh.edu/soc_facpub

Part of the Sociology Commons

Comments

This is an Accepted Manuscript. The final publication is available at Springer via https://dx.doi.org/10.1007/

s10113-015-0914-y

\section{Recommended Citation}

Hamilton, L.C., J. Hartter, B.D. Keim, A.E. Boag, M.W. Palace, F.R. Stevens \& M.J. Ducey.2016. “Wildfire, climate, and perceptions in northeast Oregon." Regional Environmental Change16:1819-1832. doi: 10.1007/s10113-015-0914-y

This Article is brought to you for free and open access by the Sociology at University of New Hampshire Scholars' Repository. It has been accepted for inclusion in Sociology Scholarship by an authorized administrator of University of New Hampshire Scholars' Repository. For more information, please contact Scholarly.Communication@unh.edu. 
Authors

Lawrence C. Hamilton, Joel N. Hartter, Barry D. Keim, Angela E. Boag, Michael W. Palace, Forrest R. Stevens, and Mark J. Ducey 
Hamilton LC, Hartter J, Keim BD, Boag AE, Palace MW, Stevens FR, Ducey MJ (2016) Wildfire, climate, and perceptions in northeast Oregon. Regional Environmental Change doi: 10.1007/s10113-015-0914-y

Authors' draft: final publication at Springer via http://dx.doi.org/10.1007/s10113-015-0914-y

\section{WILDFIRE, CLIMATE, AND PERCEPTIONS IN NORTHEAST OREGON}

Lawrence C. Hamilton ${ }^{1}$

Carsey School of Public Policy

University of New Hampshire

Durham, NH 03824

Joel Hartter

Environmental Studies Program

University of Colorado

Boulder, CO 80309

and

Carsey School of Public Policy

University of New Hampshire

Durham, NH 03824

Barry D. Keim

Department of Geography and Anthropology

Louisiana State University

Baton Rouge, LA 70803

Angela E. Boag

Environmental Studies Program

University of Colorado

Boulder, CO 80309

Michael W. Palace

Institute for the Study of Earth, Oceans and Space

University of New Hampshire

Durham, NH 03824

Forrest R. Stevens

Department of Geography and Geosciences

University of Louisville

Louisville, KY 40292

Mark J. Ducey

Department of Natural Resources and the Environment

University of New Hampshire

Durham, NH 03824
Lawrence.Hamilton@unh.edu

Joel.Hartter@colorado.edu

Keim@1su.edu

Angela.Boag@colorado.edu

Michael.Palace@unh.edu

Forrest.Stevens@louisville.edu

MJDucey@unh.edu

1 corresponding author 


\begin{abstract}
Wildfire poses a rising threat in the western US, fueled by synergies between historical fire suppression, changing land use, insects and disease, and shifts toward a drier, warmer climate. The rugged landscapes of northeast Oregon, with their historically forest and resource-based economies, have been one of the areas affected. A 2011 survey found area residents highly concerned about fire and insect threats, but not about climate change. In 2014 we conducted a second survey that, to explore this apparent disconnect, included questions about past and future summertime (fire season) temperatures. Although regional temperatures have warmed in recent decades at twice the global rate, accompanied by increasing dryness and fire risks, the warming itself is recognized by only forty percent of our respondents. Awareness of recent warming proves unrelated to individual characteristics that might indicate experience on the land: oldtimer vs. newcomer status, year-round vs. seasonal residence, and ownership of forested land. Perceptions of past warming and expectations of future warming are more common among younger respondents and less common among Tea Party supporters. The best-educated partisans stand farthest apart. Perceptions about local temperatures that are important for adaptation planning thus follow ideological patterns similar to beliefs about global climate change.
\end{abstract}

\title{
1. Introduction
}

Wildfires pose a rising threat in many parts of the western US. Dennison et al. (2014) observe upward trends in fire frequency and area over 1984-2011, especially in the southern and mountain ecoregions of the West. In May 2015, the USDA Forest Service Chief said, "we expect 2015 to continue the trend of above average fire activity" (USDA 2015). Climate change and its synergy with insect pests such as the mountain pine beetle (Weed et al. 2015), along with a fuel buildup caused by historical fire suppression and reductions in active management (Hartter et al. 2015), contribute to these trends and will likely exacerbate them in the future (Peterson et al. 2014; Stavros et al. 2014). Communities and land managers in fire-threatened regions have urgent needs for mitigation to reduce fire risks, and adaptation to improve ecosystem resilience in the face of changing climate and fire regimes (Duguy et al. 2013; Moritz et al. 2014).

Wildfire, the most influential natural disturbance within temperate forest ecosystems (Bond and van Wilgen 1996; Barnes et al. 1998), annually affects around $4,500 \mathrm{~km}^{2}$ in the US. Wildfire protection funds for federal agencies have averaged $\$ 3.13$ billion annually from 2002 to 2012, and suppression alone by federal agencies has averaged $\$ 712$ million annually (1985-2013) (Gorte 2013; National Interagency Fire Center 2013). In its July 2015 review of fire suppression, the USDA Forest Service noted that those numbers are on the rise as fires have grown bigger, fire season longer, and damage more catastrophic (USFS 2015). Higher temperatures and greater atmosphere moisture loading produce significant increases in the intensity and frequency of large thunderstorms with lightning, a main ignition source (Overpeck et al. 1990). Trends toward warmer, drier winters in some regions, together with large areas of mature, often dense stands with a legacy of fire prevention, an insect epidemic of historically unprecedented proportions, and increased ignition sources have combined to create dangerous conditions that could affect millions of acres (Cain and Hayes 2007, Kurz et al. 2008). 
For people living in regions where large tracts of forest lands are unhealthy and overstocked, the wildfire threat has been unmistakable. However, its possible connections to climate change, though widely cited by scientists, are less widely acknowledged among the public (Hamilton et al. 2012). Some mitigation and adaptation steps can be motivated by experience and local conditions, without referring to global change. Climate-wildfire connections are prominent in research, however, and necessarily inform what plans and policies might be wise for the future (Grimm et al. 2013; Sample and Bixler 2014; Hart et al. 2015). This gap between scientific and public perceptions on wildfire parallels the gap between scientific and public understanding of climate change in general (Cook et al. 2013).

The remote, dry and mountainous lands of northeast Oregon have been among those western US regions experiencing more wildfires since the mid-1980s, coinciding with regional warming. Looking ahead, projections downscaled from global models foresee further warming and less precipitation in this region, leading to reduced soil water storage and snow water equivalent (Alder and Hostetler 2013). The National Research Council projects from two to more than sixfold increase in the area burned in this region (relative to its 1950-2003 median), from regional changes accompanying a $1{ }^{\circ} \mathrm{C}$ rise in global average temperature (NRC 2011:180).

Forests historically have been a mainstay of northeast Oregon's economy and central to the lifestyles as well as livelihoods of many who live there (Hartter et al. 2015). A 2011 survey of 1,500 northeast Oregon residents found that most view forest problems as direct threats to their home communities. Global warming, however, is seen as a less serious threat (Hamilton et al. 2012). To learn more about this perceptual disconnect between fire danger and climate, a new survey of 1,700 residents conducted in 2014 asked people how they think recent summer temperatures in this region compared with those of 30 or 40 years ago, and similarly, what they expect 20 years from now. Given the physical changes, do contrasting perceptions about local warming reflect different levels of experience with the land, such as newcomers vs. oldtimers or seasonal vs. year-round residents (Qin 2015; Dickinson et al. 2015)?

Alternatively, to what extent do perceptions reflect ideological divisions, such as those seen on national surveys (Goebbert et al. 2012; Howe and Leiserowitz 2013; Marquart-Pyatt et al. 2014; McCright et al. 2014; Myers et al. 2013; Shao 2015)? After setting the context of climate and fire trends in this region, we turn to the 2014 surveys to examine the social bases of local warming perceptions.

\section{The Blue Mountain Ecoregion in Oregon}

The Blue Mountain Province-Oregon (BMP-OR, $62,000 \mathrm{~km}^{2}$ ) is the largest section of the Blue Mountain Province, an ecoregion that encompasses a large fraction of Oregon along with portions of two other states. Within this ecoregion, our study focuses on seven northeast Oregon counties that contain significant forested area: Baker, Crook, Grant, Umatilla, Union, Wallowa and Wheeler (Figure 1). BMPOR ranges from 900 up to 3,000 meters above sea level, encompassing diverse landscapes of rugged mountains, steep valleys and plateaus. The Cascades Mountains to the west create a rain shadow that keeps eastern Oregon drier than western parts of the state. Average annual precipitation was $46 \mathrm{~cm}$ over 1981-2010, with relatively little in late summer and early fall. Natural grasslands occur sporadically throughout lower elevations, but coniferous forest comprises 40 percent of the native vegetation. Much of the land is managed as four national forests (Ochoco, Umatilla, Wallowa-Whitman and Malheur) or by 
the Bureau of Land Management. BMP-OR contains six designated wilderness areas, the Hells Canyon National Recreation Area and most of the Umatilla Indian Reservation.

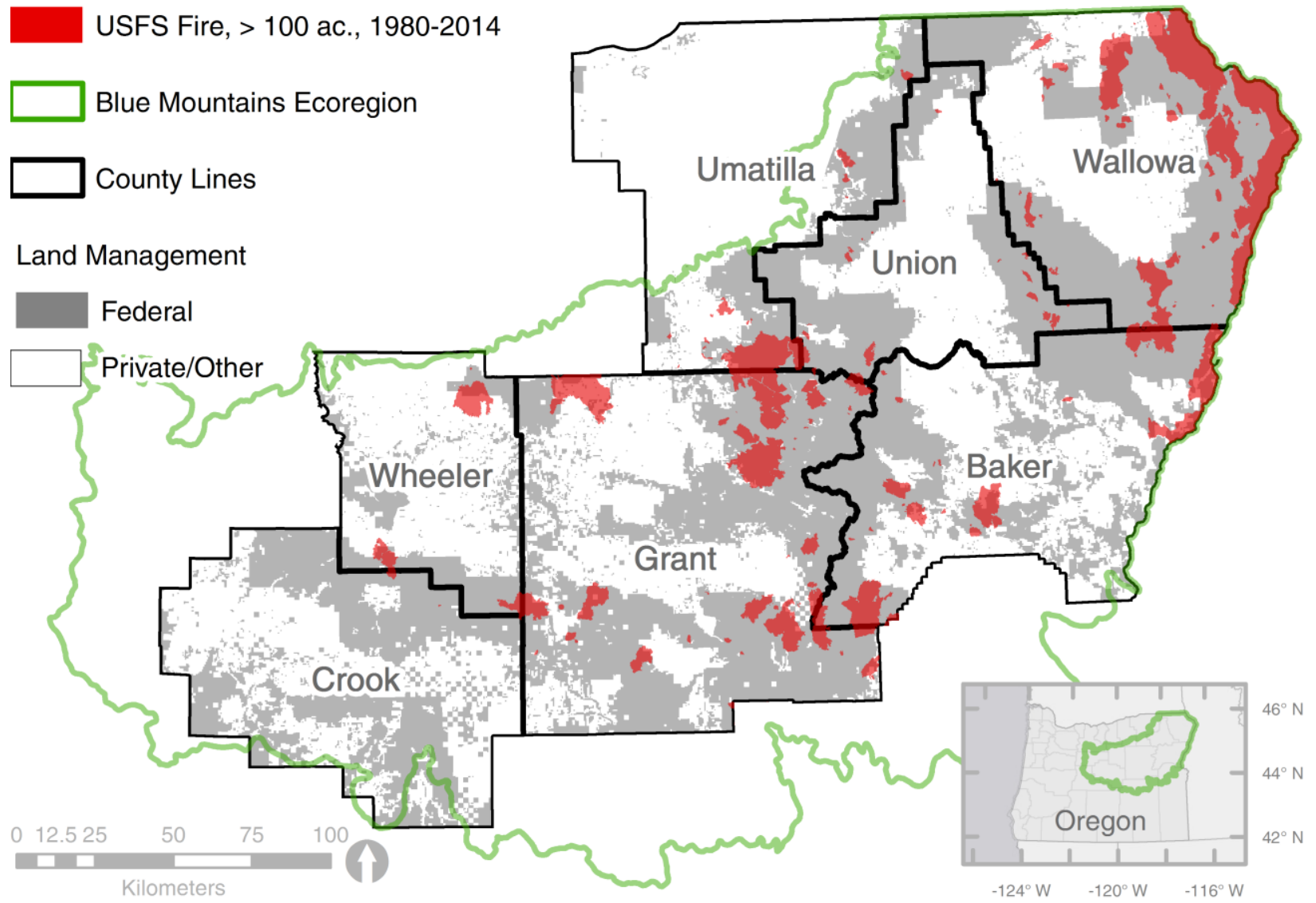

Figure 1: Map of the seven northeast Oregon counties surveyed in 2014

Fire is common in the BMP-OR due to relatively low precipitation, abundant fuel, and thunderstorm activity (Heyerdahl et al. 2001). Forests currently are threatened by insect outbreaks and at risk for catastrophic wildfire (Toman and Shindler 2003; Daily and Welch 2005). In addition, changes in forest structure, fire regimes, species assemblages and riparian conditions reflect more than a century of environmental modifications. In recent decades the region has seen unprecedented levels of endemic tree disease, mortality and fire (Langston 1995) that affect not only forest health but also visual quality, wildlife habitat, stream sedimentation and timber values (McMillin and Fettig 2007).

Forestry, historically a key part of the regional economy, has fallen steeply since the mid-1990s through a combination of global competition, mill closures, and reduced availability of timber. There has been some growth in service-sector jobs, and outmigration due to lost primary-industry jobs is partially offset by inmigration of people mostly from more urban areas. Newcomers are drawn by northeast Oregon's open landscapes and natural amenities. On public forest lands, less active management together with fire suppression has led to unnaturally dense stands, growth of understory vegetation, and accumulation of 
deadwood fuel loads. In dry conditions and thunderstorm season these conditions become highly combustible, posing obvious threats to forests, watersheds, wildlife and homes.

\section{Data and Methods}

Climate, weather and wildfire data provide an objective context for survey questions about the perceptions of area residents.

\subsection{Climate and weather indicators}

Long-term climate indicators were derived from National Oceanic and Atmospheric Administration data on eastern Oregon climate divisions 6, 7, 8 and 9 (NOAA 2015). We calculated temperature anomalies for each division and month by subtracting their 1981-2010 means. Anomalies were then averaged across the four divisions and the months June through September. Average correlation among monthly temperature anomalies for the four eastern Oregon climate divisions over 1,438 months from 1895 to fall 2014 is 0.91, and the first principal component explains 93 percent of their total variance. Both results support combination into one regional index. Reasonable alternatives such as using monthly maximum temperatures instead of means, or setting aside any one division, yield indexes with similar trends and properties.

Two other long-term indicators measuring dryness were also derived from NOAA (2015): monthly precipitation (mm), and monthly Palmer Drought Severity Index or PDSI (Palmer 1965), both of which we averaged for June through September. Precipitation and PDSI correlate less strongly across divisions than temperature anomalies do, so our regional dryness indicators are more approximate. Even so, they predict wildfire frequencies.

For a daily index of regional temperatures during the 2014 survey interview period, we used data from the four operating United States Historical Climatology Network stations in this region - Baker, Pilot Rock, Prineville and Wallowa (Menne et al. 2009; USHCN 2015). We calculated temperature anomalies relative to 1981-2010 daily normals for each station and then defined the mean anomaly as a regional index. Despite the distance between stations, daily anomalies are well correlated, supporting combination into

one index. The first principal component explains $90 \%$ of their daily variance over July 1 to November 30 2014.

\subsection{Wildfire modeling}

Annual wildfire counts for eastern Oregon were extracted from a US Forest Service dataset of Region 6 fire history 1900-2014. Points of origin represent locations at which fires began. This dataset is maintained at the Forest and District level and is associated with the Fire Statistics System (FIRESTAT). Data were provided by the Forest Service, US Department of Agriculture (April 2015). The fires, mainly but not exclusively on public lands, were binned into size classes including 100 acres $\left(404,686 \mathrm{~m}^{2}\right)$ or more, which we characterize as "medium to large" fires. (Standard size classes such as under 100 acres, 100 to 1,000 , and more than 1,000 are widely used in reports by state and federal agencies.) Lightning 
ignitions of fires less than 100 acres were viewed in our analysis as a proxy for the intensity of "dry thunderstorms" - a firefighters' description of storms that produce lightning but little rain.

To model the frequency of medium to large fires we employ negative binomial regression with robust standard errors, suitable for overdispersed (variance $>>$ mean) count data (Hamilton 2013). Predictors in this model are fire-season temperature, precipitation and drought severity as described in 3.1, along with the number of small (<100 acres) lightning ignitions. We also include year among the predictors to adjust for a linear trend reflecting non-climate factors such as fuel buildup or less active management.

\subsection{Survey research}

A random-sample telephone survey supplied data on public perceptions about forest, wildfire, and climate issues (Boag et al. 2015). We carried out a telephone survey in late summer and fall 2014, sampling the general public and forest landowners in Wallowa, Union, Baker, Crook, Umatilla, Grant and Wheeler Counties in northeastern Oregon. A total of 1,752 surveys were completed, including 235 surveys of forest landowners (owning 10+ acres of land at least 25\% covered with trees). Surveys lasted 10 to 15 minutes and were conducted by trained interviewers at the University of New Hampshire Survey Center using random digit dialing (RDD) to both landline and cell telephone numbers. The overall response rate was 33\% (36\% for landline, 29\% for cell phones), calculated by the RR4 standard defined in AAPOR (2006). Probability weights allowed minor adjustments toward a more representative sample. The weighting scheme used (similar to that in Hamilton et al. 2014), while avoiding large changes, includes adjustments for design bias involving number of people in a household, and deliberate oversampling to achieve representation from smaller counties and forest landowners. Weights also adjust the demographic profile to match a census age/sex table for these counties. Boag et al. (2015) present preliminary results including a graphical view of the weighting process, and comparisons with the earlier survey in 2011.

Table 1 gives variable definitions and summary statistics. For this paper we focus on two questions, pastemp and futemp, that asked people how they think recent summer temperatures in their region compare with those of 30 or 40 years ago, or with those over the next 20 years. The questions intentionally (and appropriately for a survey) aim at subjective perceptions rather than answers in degrees. They were designed to explore a seeming disconnect found by our 2011 survey, where 74 percent considered wildfire a serious threat to themselves or their community, but only half as many said the same about global warming (Hamilton et al. 2012). As described in later sections we know objectively that average summer temperatures, high and low extremes, dryness and wildfire frequencies all increased over this period; the dryness and fire effects in particular have been tangible. Moreover, a number of regional and national reports pointed out the connection between climate and fires. The temperature questions on our 2014 survey were intended to find out whether people noticed or acknowledged local warming, without mentioning possible connections to global warming. People evidently made such connections themselves, however, so their local temperature perceptions prove socially more complex than wildfire perceptions (Hamilton et al. 2014). 
Table 1: Definitions and weighted summaries variables from the 2014 northeast Oregon survey $(n=1,752)$. Shown with codes used for logit regression analysis in Table 2.

\section{Independent variables}

Age - Respondent's age in years (range 18 to 96 years, mean 50 years).

Gender - Female $(1,51 \%)$ or male $(0,49 \%)$

Education - Postgraduate (2, 14\%), college graduate (1, 26\%), some college or technical school $(0,32 \%)$, high school or less $(-1,28 \%)$.

Party - Tea Party supporter (2, 29\%), Republican (1, 20\%), Independent (0, 16\%) or Democrat (-1, 23\%).

Employed - Employed full time (1, 46\%) or not $(0,54 \%)$.

Newcomer - Lived in this county less than 10 years $(1,26 \%)$ or 10 years or more $(0,74 \%)$.

Seasonal - Seasonal resident $(1,6 \%)$ or live in this county year-round $(0,94 \%)$.

Forest - Own 10 or more acres of forest land (1, 8\%) or do not $(0,92 \%)$.

Temperature - Mean daily temperature anomaly (relative to 1981-2010 normals for each station) for four regional USHCN weather stations (for August through October 2014 , range -4.7 to $+6.3^{\circ} \mathrm{C}$, mean $1.8^{\circ} \mathrm{C}$ ).

Temp2 - Mean temperature anomaly for the interview and previous day (range -4.6 to $+7.3^{\circ} \mathrm{C}$, mean $1.1^{\circ} \mathrm{C}$ )

\section{Dependent variables}

Pastemp - Which of the following statements about past climate in this region do you believe is most accurate? Northeast Oregon summer temperatures over the past 20 years ...

Have been warmer, on average, than summers 30 or 40 years ago (1, 40\%).

Have been about the same, on average, as summers 30 or 40 years ago (0,39\%).

Have been cooler, on average, than summers 30 or 40 years ago $(0,11 \%)$.

Don't know/no answer (0, 10\%)

Futemp - Which of the following statements best describes your belief about future climate in this region? Northeast Oregon summer temperatures over the next 20 years are likely to be ...

Warmer, on average, than summers of the past 20 years $(1,43 \%)$.

About the same, on average, as summers of the past 20 years $(0,44 \%)$.

Cooler, on average, than summers of the past 20 years $(0,6 \%)$.

Don't know/no answer (0, 7\%).

Climate - Which of the following three statements do you personally believe?

Climate change is happening now, caused mainly by human activities (1, 46\%).

Climate change is happening now, but caused mainly by natural forces $(0,39 \%)$.

Climate change is NOT happening now $(0,9 \%)$.

Don't know/no answer (0,6\%). 


\subsection{Field Interviews}

In July 2014 and May-August 2015, researchers visited communities in the seven-county study area. During that time, we met with stakeholders, including non-industrial private forest landowners, residents who are not forest owners, state and federal agency representatives, civic leaders, and environmental and natural resource related organizations. We also made town-hall type presentations to public or stakeholder groups, describing our preliminary results and inviting feedback. Discussions were informal, on topics including wildfire, impression of forest health and use in the area, and the changing environment. Results from these discussions informed design of our survey questions and the interpretation of survey results, but are not a focus of analysis here. Field interview results will be written up once that stage of the research is completed.

\section{Results}

Analysis confirms the connection between wildfire frequency and climate. Although climatic records show regional warming over the past four decades, the survey finds many residents unaware of this trend. We follow up to profile those who do or do not acknowledge past warming, or expect warming in the future.

\subsection{Wildfires and climate}

Average monthly June-September temperatures in eastern Oregon have risen over the past century, from a median around $15.6{ }^{\circ} \mathrm{C}\left(60.1^{\circ} \mathrm{F}\right)$ during $1895-1914$ to $17.4^{\circ} \mathrm{C}\left(63.4^{\circ} \mathrm{F}\right)$ during $1995-2014$, the coolest and warmest 20 -year periods on record (from NOAA 2015 climate divisions data). Recent warming, since 1970, has been accompanied by more frequent wildfires: a statistically significant $(p=.01)$ upward trend averaging 2.3 additional fires per decade. Figure 2 graphs the annual number of fires greater than 100 acres in eastern Oregon 1970-2014. One exceptionally bad year, 1986, punctuates a shift toward more frequent fires. The Unit Forester stationed in La Grande and Baker City recalls 1986 as a "perfect storm" of hot and dry weather followed by consecutive days of extremely active dry lightning storms. Resources tapped early in the fire season set the stage for more and larger fires in the following days as the system was overwhelmed. Smaller fires became larger fires because suppression resources were stretched thin. Baker and Wallowa counties were hit the hardest (Mark Jacques, personal communication). 


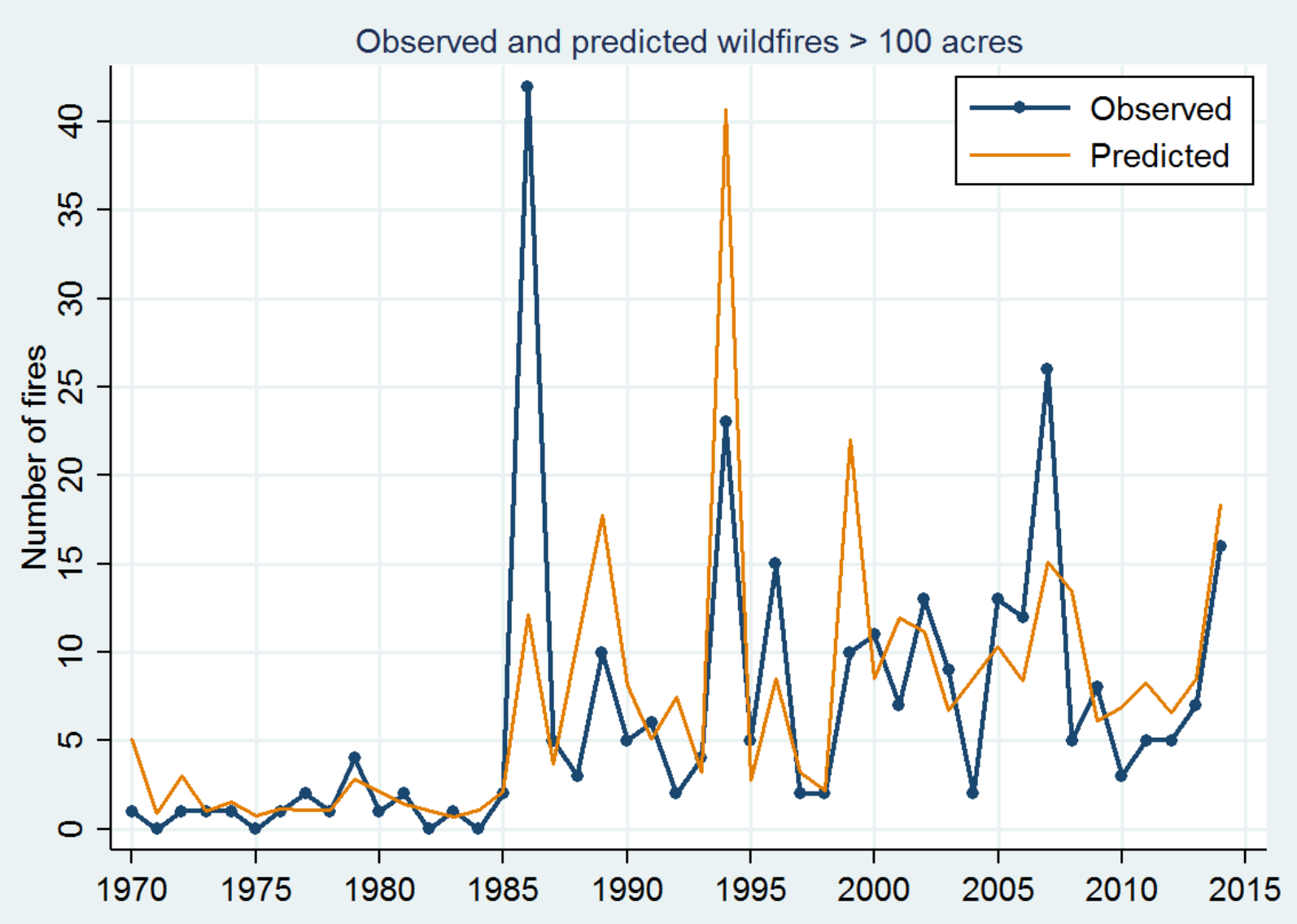

Figure 2: Observed and predicted number of medium to large wildfires in eastern Oregon 1970-2014

Figure 2 also plots predictions from a negative binomial regression of wildfire frequency on June through September temperature anomaly, precipitation, PDSI, number of small lighting-ignited fires, and overall upward trend. Modeling falls short of the exceptionally high count in 1986, but otherwise gives an approximate fit to the fire counts (Wald $\chi^{2} p<0.001$ ). All predictors including year have significant effects. This analysis tells us that (1) climatological factors which in the short term manifest as weather, but in their longer trends reflect climate change, contribute to the frequency of medium to large fires; and that (2) net of weather/climate factors, there remains an overall upward trend that plausibly represents human factors including fire suppression and less active management. The human factors could also include improvements in fire detection and decreasing small-fire suppression by logging crews. Climate and human factors are sometimes posed as competing explanations for rising wildfire frequency, but this analysis confirms that both are important.

\subsection{Observed summer warming}

Figure 2 displayed results from a statistical model predicting wildfire frequency partly from climatic factors, and especially from dryness which rises with temperature. Figure 3A plots eastern Oregon fire- 
season (June through September) temperature anomalies over 1895-2014. The past 20 years include six of the 10 warmest in this 120-year record. A lowess regression curve in Figure 3A highlights the steppause-step pattern of early-20th century warming, mid-20th century slowdown, and late-20th/early-21st century rise in temperatures that forms the signature of global warming (IPCC 2013). The June through September warming in eastern Oregon over these 120 years has been steeper than global trends, however.

\section{Eastern Oregon fire season (JJAS) temperature}
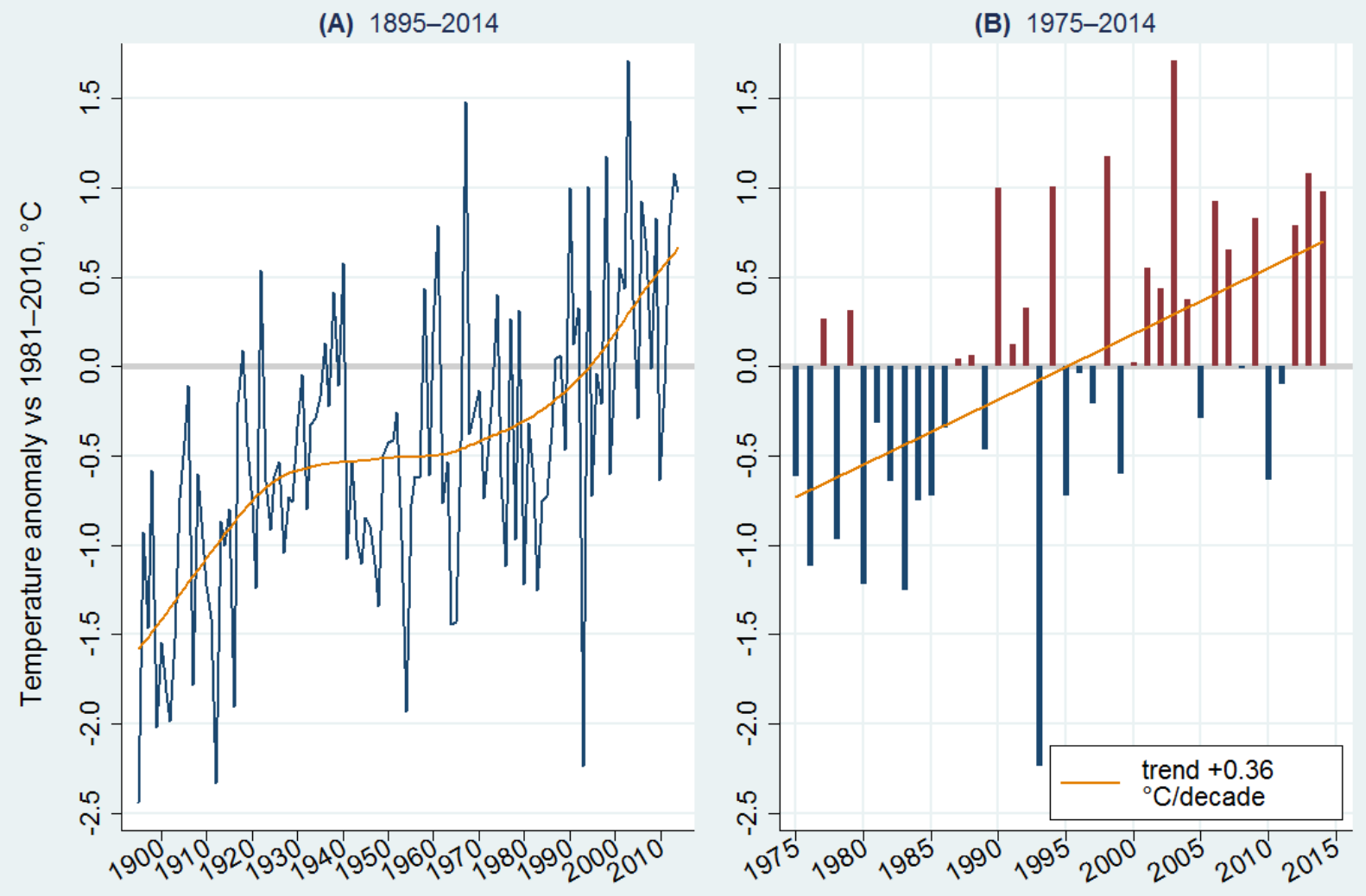

Figure 3: a June through September temperature anomaly in eastern Oregon 1895-2014, with lowess regression curve; b June through September temperature anomaly 1975-2014, with linear trend

The right-hand panel, Figure 3B, isolates temperature anomalies from just the past four decades, the timeframe of our pastemp survey question. Over this period eastern Oregon summers warmed at more than twice the global rate $-0.36^{\circ} \mathrm{C} /$ decade, compared to $0.17^{\circ} \mathrm{C} /$ decade globally (NASA 2015). Spikes from the horizontal line in Figure 3B depict above- and below-average temperatures. The cool summer of 1993 has been attributed to the eruption of Mt. Pinatubo in the Philippines (Halpert et al. 1994). A linear trend gains $1.4^{\circ} \mathrm{C}$, about twice the change in global temperatures over this period. 


\subsection{Perceived summer warming}

Statistically significant warming is clear in Figure 3B, although experientially the trend's magnitude is small relative to the contrast between a warm and a cool summer day. Warming temperatures affect drying conditions, however, which were widely mentioned in field interviews. The Palmer drought severity index correlates -0.56 with fire-season temperature anomalies over 1970-2014, and -0.45 with mean precipitation. Nevertheless, only forty percent of the survey respondents report that summer temperatures have been warmer over the past 20 years than they were 30 or 40 years ago (Figure 4A). Almost as many (39 percent) report the less accurate though experientially plausible perception that temperatures are about the same, while 11 percent counterfactually perceive that recent summers have been cooler. Only 10 percent overall said they did not know, or gave no answer. Even among newcomers and younger respondents, the don't know/no answer (DK/NA) fractions are below 20 percent. Most preferred to give some answer; we later test whether the answers they gave differ from those of older or longtime residents.
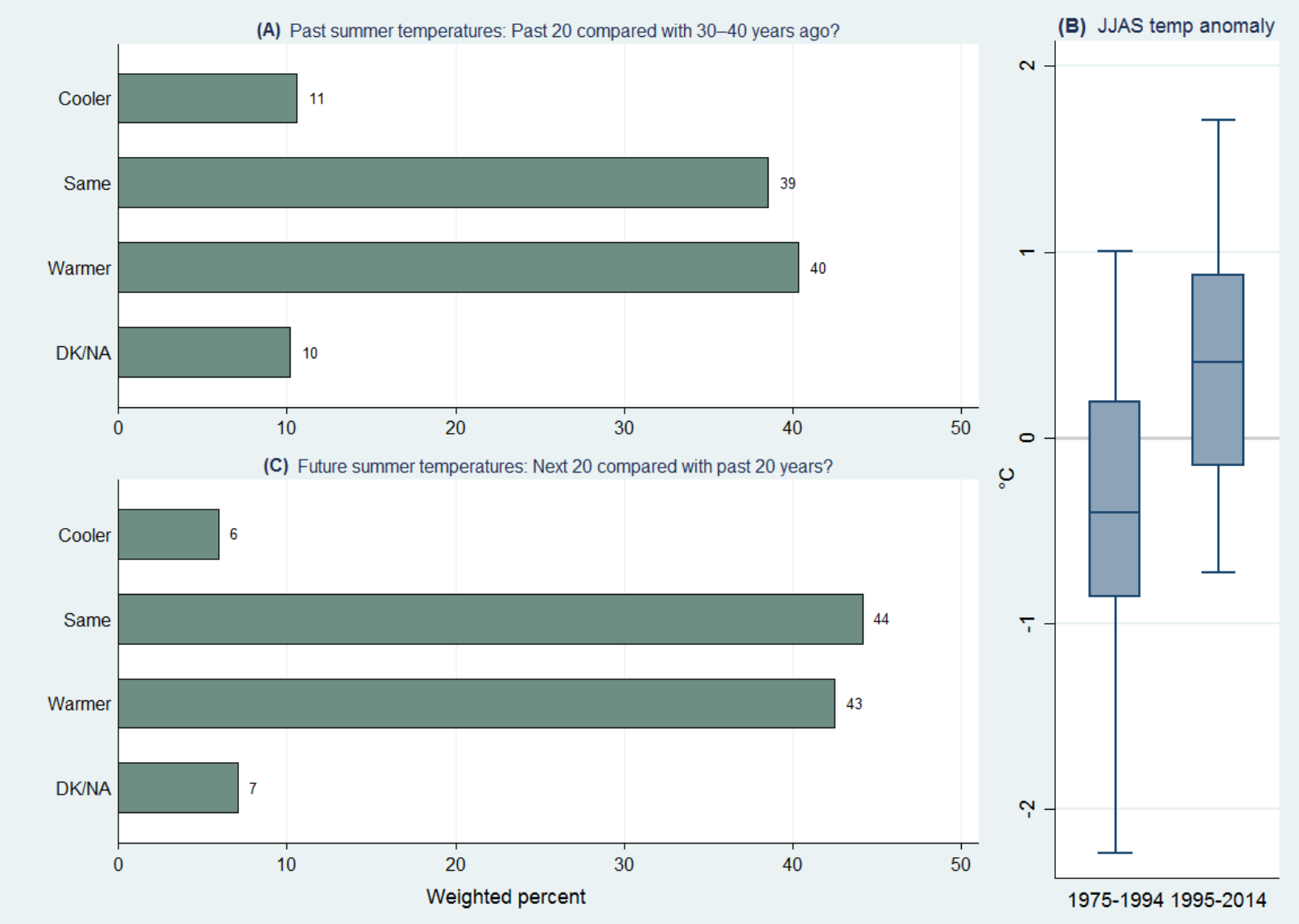

Figure 4: a Survey responses about past summer temperatures; $\mathbf{b}$ summer temperature anomalies for 1975-1994 and 1995-2014 (box plots indicate the median, quartiles and extreme values); c survey responses about future summer temperatures 
Box plots in Figure 4B compare observed temperature distributions for these two periods. Median summer temperature anomaly for the past 20 years is about $0.8^{\circ} \mathrm{C}\left(1.5^{\circ} \mathrm{F}\right)$ warmer than the median for the previous two decades. Although the median degree change by itself might be too small to experience directly, the whole distribution, including high and low extremes, drifted upwards, while vegetation, snowpack and dryness changed too. Median summer precipitation declined by one-third over this period, going from $22.6 \mathrm{~mm}$ in 1975-1994 to $15.2 \mathrm{~mm}$ in 1995-2014. The median PDSI declined from 0.21 to 0.51 . Thus, the past 20 years were warmer and drier than the previous 20 , contributing to the increase in wildfire risk.

Thoughts about future warming (Figure 4C) resemble perceptions regarding the past. Although few people think summers will be cooler over the next 20 years, 44 percent think they will stay about the same, and just 43 percent expect warming. Given these expectations there would be weak public support for management or planning that anticipates climatic conditions changing systematically in the future although scientists warn this is likely to happen (IPCC 2013; NRC 2011).

\subsection{Who believes it is warming?}

In our discussions with northeast Oregon residents, their concerns about the related problems of wildfire, drought, insects and forests health came up often. Other topics with high salience involved the region's changing demographics, as people moved away following loss of resource-based jobs, while others moved in, drawn by the region's recreation and lifestyle amenities. Some long-term residents view the newcomers skeptically as outsiders with a different culture and relationship to the land. They might characterize newcomers, and especially seasonal residents, as more often disengaged or opposed to active forest management through tree-cutting, and less aware of the fire and insect risks that can worsen without active management. New and old residents who own forest lands reference their perceptions to personal experience and the landscapes that were often in view as we talked. The telephone survey contained items to identify key subgroups mentioned in these conversations, such as forest landowners, oldtimers or newcomers, and year-round or seasonal residents. We also asked general questions about age, gender, education and political party identification.

Table 2 displays the results of models that test how this suite of region-specific and general respondent characteristics, along with county of residence and temperature anomaly on the interview and previous day, predict responses about past or future local temperatures, or about global climate change. Results shown are odds ratios describing multiplicative effect of a unit increase in independent variables on the odds of favoring a response that recent temperatures are warmer (pastemp $=1)$, future temperatures will be warmer (futemp $=1)$, or humans are changing the climate $($ climate $=1)$. 
Table 2: Odds ratios from weighted logit regression of climate beliefs on individual characteristics and two-day temperature anomaly (estimation sample $n=1,545$ ). Intercept dummy variables representing separate counties are included in each model but not shown here.

\begin{tabular}{llll}
\hline \hline & $\begin{array}{l}\text { Past } \\
\text { Warming } \\
\text { Pastemp }\end{array}$ & $\begin{array}{l}\text { Future } \\
\text { Warming } \\
\text { Futemp }\end{array}$ & $\begin{array}{l}\text { Climate } \\
\text { Changing } \\
\text { Climate }\end{array}$ \\
& & & \\
Age & $0.989^{*}$ & $0.983^{* *}$ & $0.981^{\star *}$ \\
Female & 1.170 & 1.087 & $1.491^{*}$ \\
Education & 1.125 & $1.231^{*}$ & $1.354^{\star *}$ \\
Party & $0.692^{* * *}$ & $0.579^{* * *}$ & $0.431^{* * *}$ \\
Education $\times$ party & $0.854^{*}$ & $0.807^{* *}$ & $0.811^{\star *}$ \\
Employed & 1.030 & 0.863 & 1.146 \\
Newcomer & 1.050 & 1.252 & 0.998 \\
Seasonal & 0.760 & 0.928 & 0.822 \\
Forest & 0.877 & 1.091 & 0.853 \\
Temp2 & 1.031 & 1.048 & 1.049 \\
& & \\
\hline \hline
\end{tabular}

${ }^{*} p<.05,{ }^{* *} p<.01,{ }^{* * *} p<.001$

The first model in Table 2 finds that age, political party and the interaction of education with party significantly predict respondents' belief that recent summers were warmer than those of 30 or 40 years ago. As noted earlier, summers have warmed, but older respondents are less likely to perceive this. Republicans and Tea Party supporters also less often perceive that recent summers have been warmer. Repeating this pattern, the second and third models in Table 2 find that older respondents and Republicans or Tea Party supporters less often think that future northeast Oregon summers will be warmer, or more broadly that humans are changing Earth's climate.

Education shows positive main effects both on future warming and anthropogenic climate change. The main effect of education on futemp, for example, indicates that among respondents who identify as political Independents (party $=0$ ), the odds of expecting future warming rise by 23 percent (are multiplied by 1.231) with each level of education. Education main effects on climate go in the same direction but stronger: among Independents the odds of believing that humans are changing the climate rise by 35 percent (are multiplied by 1.354) with each level of education. Party, in turn, has significant main effects on pastemp, futemp and climate but in the opposite direction: among respondents with some college or technical school education (education $=0$ ), odds of believing in anthropogenic climate change decrease with each level of party (Democrat, Independent, Republican, Tea Party).

Past work has found that weather anomalies can impact climate-related beliefs (Hamilton and Stampone 2013; Hamilton and Lemcke-Stampone 2014; McCright et al. 2014; Shao et al. 2014; Zaval et al. 2014). Even where significant, however, such effects tend to be weaker than ideological effects. Other authors do not find weather effects in their data (Marquart-Pyatt et al. 2014). Taken together, the divergent findings suggest weather effects are at best contingent. Our northeast Oregon analysis detected only weak and statistically non-significant daily weather effects on climate responses. 
Interactions between education and politics have been widely reported regarding climate and other environment or science topics (e.g., Hamilton 2011; McCright and Dunlap 2011), including some questions on our 2011 northeast Oregon survey (Hamilton et al. 2014). If education $\times$ politics interactions exist but are not tested, that could lead to underestimating the effects of both education and politics. In Table 2 we see that such interactions prove significant regarding all three climate questions, and have the direction expected from previous research (Figure 5). Among Democrats and Independents, college graduates are more likely to think that recent summers have been warmer than past, future summers will be warmer than recent, and humans are changing Earth's climate. Among Republicans and especially Tea Party supporters on the other hand, college graduates are less likely to think the past has warmed, the future will warm, or that humans are changing the climate. Consequently, the partisan divisions on all three topics grow wider with education.
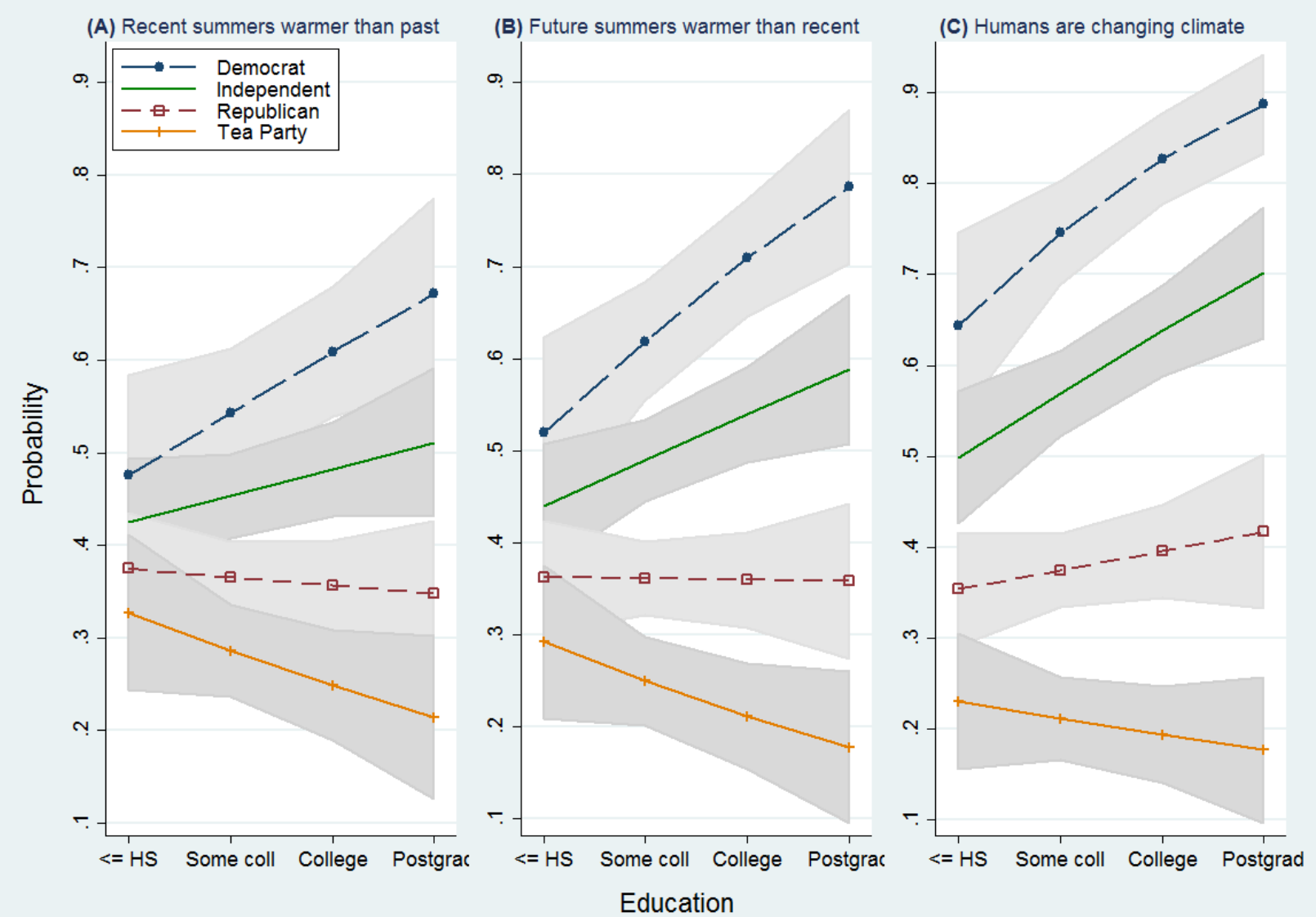

Figure 5: Beliefs about a past and $\mathbf{b}$ future summer temperatures, and $\mathbf{c}$ global climate change, as a function of education and political party. Adjusted marginal plots from logit regression models in Table 2

Responses to our question about past local temperatures thus have the same predictors as personal beliefs about anthropogenic climate change. Although past temperatures are observed and to some degree experienced phenomena, three presumably experience-linked characteristics (newcomer, seasonal and 
forest) have no effect on the answers. Age, a fourth experience-linked characteristic, actually decreases the odds of accuracy about past temperatures. Our results suggest that past temperatures perceptions instead are influenced by a worldview or ideological framework that links them to global-warming beliefs. This framework also shapes thoughts about future temperatures, which are a critical element in forest management strategies for changing climate and fire regimes in the decades ahead.

\section{Discussion}

McCaffrey et al. (2015) review more than 200 social-science studies related to wildfire management, many of them focused on support for mitigation activities. Although climate change has become a prominent theme of physical research on wildfire risks, and is important for adaptation or mitigation plans, climate perceptions have not received corresponding attention in this social research. Our study addresses that gap by examining perceptions about past and future trends in a region where both climate and fire risks clearly are changing.

The age, education and political effects on climate perceptions shown in Table 2 resemble those seen with other climate and environmental beliefs in northeast Oregon (Hamilton et al. 2014) and elsewhere (e.g., Hamilton and Safford 2015). Older residents, who could have longer memories, are less likely than younger respondents to know or guess that summers have warmed. This negative effect from age would be counter-intuitive if warming perceptions reflect lived experience, but makes sense if they instead reflect outlook or general beliefs such as the reality of anthropogenic climate change. Age negatively affects responses to our future warming and climate change questions as well, following patterns seen with environmental topics in many other studies (e.g., Buttel 1979; Van Liere and Dunlap 1980; Jones and Dunlap 1992; Hamilton et al. 2015). Explanations for such age effects partly involve cohort dynamics. Concern about environmental problems gained salience in education and culture following environmental reforms of the 1970s. The long time horizons of environmental threats may affect perspectives differently depending on life stage as well.

Contrary to expectations, three subgroups presumed to have greater experience with the land - forest landowners, year-round residents, and long-term residents - are neither more nor less likely than others to know that summers have warmed. Together with the negative age effects, the non-effects from these factors suggest that warming perceptions often derive from sources other than experience. Our Oregon results parallel those of other studies where perceptions about local climate proved related to ideology or general climate beliefs. For example, Howe and Leiserowitz (2013) observe that subjective experience of local temperatures depends on prior beliefs about global warming - particularly among those who do not think global warming is happening. Goebbert et al. (2012) report that cultural biases and ideology shape perceptions of local weather, with perceptions of temperature the most politicized. Indirectly consistent with these results, Shao (2015) notes that perceptions of local weather have more power than actual weather for predicting global warming beliefs. That result might partly reflect an opposite causality: people perceive unusual weather (or not) because of what they believe about climate change. These other studies employ nationwide data, however. Our analysis focused on one rural region, where landscapeconnected livelihoods and lifestyles are prominent, but those living on the land are no less prone to perceptual bias. 
One signature of the US ideological polarization on environment, science and especially climate-change issues has been the emergence of information $\times$ politics-type interactions, such as the education $\times$ party effects in Figure 5. Such interactions were first modeled from 2006 General Social Survey data (Hamilton 2008), and subsequently confirmed using other datasets and questions (Hamilton 2011; McCright and Dunlap 2011; see Hamilton et al. 2015 for a replication across 35 surveys). The interactions mean that partisan gaps are widest among information elites. Separately named but substantively overlapping theoretical frameworks that offer possible explanations include biased assimilation (McCright and Dunlap 2011; Corner et al. 2011; Borick and Rabe 2010), elite cues (Brulle et al. 2012; Darmofal 2005; Guber 2012); information processing (Wood and Vedlitz 2007); motivated skepticism (Taber and Lodge 2006) and cultural cognition (Kahan et al. 2011). These share the idea that better educated or informed individuals tend to have preferred sources or established positions on a topic. Whether they prefer science- or ideology-based sources, they more actively filter the information they acquire.

Such interactions are strongest regarding climate change, which on surveys behaves like an ideological marker comparable to self-identification by political party or a liberal-to-conservative scale (Kahan 2015). The interactions highlight limitations of an information deficit view of science communication, which holds that people express low concern about scientifically-identified problems because they lack information that scientists could provide (Burgess et al. 1998). Concern about climate change rises with education (and also with science literacy; see Hamilton et al. 2012 and Kahan et al. 2012) only among some groups of the population. Information elites such as those with more education or more interest have rich access to scientific explanations but also, if they are ideologically motivated to reject scientific conclusions, access to sources of scientific-sounding contrarian arguments to reinforce their existing beliefs (Dunlap and McCright 2015). These are general observations regarding US public perceptions about anthropogenic climate change, but our results suggest that for the ecologically consequential though numerically small warming that has occurred in northeast Oregon to date, general beliefs overshadow experience in shaping perceptions.

Perceptions about past climate have societal and social-science importance, but expectations regarding future climate are particularly important for policy. Support for adaptive planning in this region depends on perceptions about the path of future climate change. In the near term, some adaptation steps can be motivated from needs that already are apparent in the drying landscapes and declining forest health noted by many area residents. Active management of public and private forest lands, such as thinning dense stands, has public support (Boag et al. 2015) and has become a focus of innovative citizen-government collaboratives (Davis and Moseley 2015; Jones et al. 2015). On a smaller scale, individual landowners engage in activities such as brush clearing or removing ladder fuels, and express interest in learning more about forest management practices (Hartter et al. 2014, 2015). These activities are limited but useful steps toward living with a warmer, drier future, without invoking cultural resistance against the reality of climate change. Larger and more forward-looking actions encounter practical as well as perceptual challenges, because these commonly do not break even or make a profit in the short run.

However well-intentioned, individual actions are eclipsed by the threat of catastrophic wildfire - as seen all too clearly in the scale of fires throughout the West in summer of 2015. Among the many ignitions in northeast Oregon one fire, the Canyon Creek Complex, burned over 110,000 acres $\left(445 \mathrm{~km}^{2}\right)$. With more than 40 homes destroyed it ranks as Oregon's most destructive in terms of property since the 1930s. In earlier field interviews, residents had voiced worries about the potential for such fires, which in the 
summer of 2015 seemed to be coming true in northeast Oregon, Washington, California, Alaska and elsewhere around the West (Johnson and Santos 2015). The scope of this threat requires strong policy as well as individual-landowner response.

Only 46 percent of our northeast Oregon respondents believe that humans are changing Earth's climate. This fraction is lower than national levels (Hamilton et al. 2015) and far below the fraction among climate scientists (Doran and Zimmerman 2009; Funk and Rainie 2015). Three-quarters of those who do not think humans are changing the climate also do not think that future summers in northeast Oregon will be warmer - so this ideology-linked view could limit support for regional planning. Commenting in field interviews and town hall meetings on the landscape's dryness and decreasing winter snowpack, some residents referred to natural cycles rather than climate change as the reason. Framing arguments in terms of preparation for future warming and drying "whether caused by natural cycles or by climate change" could help to bypass cultural resistance to adaptation planning. It would not help build support for sacrifices to reduce greenhouse gas emissions, however, which probably are needed to avert even worse fire seasons (along with other problems) in the future. At the time of our survey in summer/fall 2014, the mild decadal-scale warming graphed in Figure 3 had not registered in most people's perceptions. Instead those perceptions seem to follow from general climate-change beliefs. Whether the direction of influence from general beliefs to local perceptions could reverse so that local change alters general beliefs, if the climate continues warming and drying, is a question for future research.

\section{Conclusion}

Eastern Oregon summers have warmed over the past four decades at more than twice the global rate. Recent warming has been accompanied by other changes including greater dryness and decreased winter snowpack, all of which contribute to the rising frequency of wildfires. Although forest health and wildfire issues are salient, climate change is much less so. A summer/fall 2014 telephone survey of more than 1,700 area residents found a majority unaware of the regional warming trend. Moreover, such awareness is no different among subgroups thought to have closer experience with the land: long-term residents, year-round residents, or forest landowners. Instead, perceptions about past warming correlate with political identity, and this partisan gap widens with education. Expectations about future warming in this region follow a similar pattern of political rather than experience-linked predictors. Thus, responses to regional-change questions parallel responses to another survey question that asked for beliefs about anthropogenic climate change itself.

Political filtering of perceptions about local climate pose challenges for forward-looking adaptation efforts, which are not costless and need to have a large scale. Cultural resistance to the concept of anthropogenic climate change might partly be offset by framing the motives for adaptation in terms of natural cycles in addition to climate change, although that would not affect the relatively low support for greenhouse mitigation. The disastrous fire season of 2015, coming after the time of our survey, underlines the urgency of changing conditions. 


\section{Acknowledgments}

The Communities and Forests in Oregon (CAFOR) project is supported by a grant from the Agricultural and Food Research Initiative of the US Department of Agriculture (2014-68002-21782). Any opinions, findings and conclusions or recommendations expressed in this material are those of the authors and do not necessarily represent the views of the USDA. Grant Foster inspired the analysis in Figure 2. We appreciate continued collaboration with Nils Christoffersen of Wallowa Resources, and with Paul Oester and Bob Parker of the Oregon State University College of Forestry Extension.

\section{References}

AAPOR (American Association for Public Opinion Research) (2006) Standard Definitions:

Final Disposition of Case Codes and Outcome Rates for Surveys. 4th ed. Lenexa, KS: American Association for Public Opinion Research.

Alder JR, Hostetler SW (2013) USGS National Climate Change Viewer. US Geological Survey. Available at: http://www.usgs.gov/climate landuse/clu rd/nex-dcp30.asp accessed 6/5/2015. doi: 10.5066/F7W9575T

Barnes B, Zak DR, Denton SR, Spurr SH (1998) Forest Ecology. New York: Wiley.

Boag A, Hartter J, Hamilton LC, Ducey M, Palace M, Stevens FR, Christoffersen N, Oester P (2015)

Forest views: Shifting attitudes toward the environment in northeast Oregon. Durham, NH: Carsey School of Public Policy. Available at: http://scholars.unh.edu/carsey/238 accessed 9/9/2015.

Bond WJ, van Wilgen BW (eds) (1996) Fire and Plants. New York: Chapman and Hall.

Borick CP, Rabe BG (2010) A reason to believe: Examining the factors that determine individual views on global warming. Social Science Quarterly 91(3):777-800. doi: 10.1111/j.1540-6237.2010.00719.x

Burgess J, Harrison CM, Filius P (1998) Environmental communication and the cultural politics of environmental citizenship. Environment and Planning A 30(8):1445-1460.

Buttel FH (1979) Age and environmental concern: A multivariate analysis. Youth and Society 10(3):237-256.

Brulle RJ, Carmichael J, Jenkins JC (2012) Shifting public opinion on climate change: An empirical assessment of factors influencing concern over climate change in the U.S., 2002-2010. Climatic Change 114:169-188. doi:10.1007/s10584-012-0403-y

Cain RJ, Hayes JL (2007) Bark beetle conditions in western forests and formation of the Western Bark Beetle Research Group. Pp. 9-24 in The Western Bark Beetle Research Group: A Unique collaboration with Forest Health Protection. US Department of Agriculture. Available at:

www.fs.fed.us/pnw/pubs/pnw gtr784.pdf accessed 6/5/2015. 
Cook J, Nuccitelli D, Green SA, Richardson M, Winkler B, Painting R, Way R, Jacobs P, Skuce A (2013) Quantifying the consensus on anthropogenic global warming in the scientific literature. Environmental Research Letters 8. doi:10.1088/1748-9326/8/2/024024

Corner A, Whitmarsh L, Xenias D (2011) Uncertainty, scepticism and attitudes towards climate change: Biased assimilation and attitude polarisation. Climatic Change 114(3-4):463-478. doi: 10.1007/s10584012-0424-6

Daily AG, Welch TK (eds) (2005) Ecology and Management of Eastern Oregon Forests: A Comprehensive Manual for Forest Managers. Manual 12. OSU Extension Service.

Darmofal, D (2005) Elite cues and citizen disagreement with expert opinion. Political Research Quarterly 58(3):381-395.

Davis, EJ, Moseley C (2015) Collaborative capacity of accelerated restoration. Ecosystem Workforce Project. Available at: http://ewp.uoregon.edu/sites/ewp.uoregon.edu/files/FS_7.pdf accessed 6/5/2015.

Dennison PE, Brewer SC, Arnold JD, Moritz MA (2014) Large wildfire trends in the western United States, 1984-2011. Geophysical Research Letters 41(8):2928-2933. doi: 10.1002/2014GL059576

Dickinson K, Brenkert-Smith H, Champ P, Flores N (2015) Catching fire? Social interactions, beliefs, and wildfire risk mitigation behaviors. Society \& Natural Resources 28(8):807-824. doi:

$10.1080 / 08941920.2015 .1037034$

Doran PT, Zimmerman MK (2009) Examining the scientific consensus on climate change. EOS 90(3): 22-23. doi: 10.1029/2009EO030002

Duguy B, Paula S, Pausas SG, Alloza JA, Gimeno T, Vallejo RV (2013) Effects of climate and extreme events on wildfire regime and their ecological impacts. Advances in Global Change Research 51:101134. doi: 10.1007/978-94-007-5772-1_6

Dunlap RE, McCright AM (2015) Challenging climate change: The denial countermovement. In Dunlap RE, Brulle RJ (eds) Climate Change and Society: Sociological Perspectives. New York: Oxford University Press 300-332. doi: 10.1093/acprof:oso/9780199356102.001.0001

Funk C, Rainie L (2015) Public and scientists' views on science and society. Pew Research Center. Available at: http://www.pewinternet.org/2015/01/29/public-and-scientists-views-on-science-and-society/ accessed 9/6/2015.

Goebbert K, Jenkins-Smith HC, Klockow K, Nowlin MC, Silva C (2012) Weather, climate, and worldviews: The sources and consequences of public perceptions of changes in local weather patterns. Weather, Climate, and Society 4:132-144. doi: 10.1175/WCAS-D-11-00044.1 
Gorte R (2013) The rising cost of wildfire protection. Headwater Economics. Bozeman. Available at: http://headwaterseconomics.org/wphw/wp-content/uploads/fire-costs-background-report.pdf accessed $12 / 4 / 2015$.

Grimm NB, Chapin FS III, Bierwagen B, Gonzalez P, Groffman PM, Luo Y, Melton F, Nadelhoffer K, Pairis A, Raymond PA, Schimel J, Williamson CE (2013) The impacts of climate change on ecosystem structure and function. Frontiers in Ecology and the Environment 11:474-482. doi:10.1890/120282

Guber DL (2012) A cooling climate for change? Party polarization and the politics of global warming. American Behavioral Scientist 57(1):93-115. doi: 10.1177/0002764212463361

Hamilton LC (2008) Who cares about polar regions? Results from a survey of U.S. public opinion. Arctic, Antarctic, and Alpine Research 40(4):671-678.

Hamilton LC (2011) Education, politics and opinions about climate change: Evidence for interaction effects. Climatic Change, 104:231-242. doi: 10.1007/s10584-010-9957-8

Hamilton LC (2013) Statistics with Stata, version 12. Belmont, CA: Cengage.

Hamilton LC, Hartter J, Stevens F, Congalton RG, Ducey M, Campbell M, Maynard D, Staunton M (2012) Forest views: Northeast Oregon survey looks at community and environment. Durham, NH: Carsey Institute. Available at: http://scholars.unh.edu/carsey/162/ accessed 6/5/2015.

Hamilton LC, Cutler MJ, Schaefer A (2012) Public knowledge and concern about polar-region warming. Polar Geography 35(2):155-168. doi: 10.1080/1088937X.2012.684155

Hamilton LC, Stampone MD (2013) Blowin' in the wind: Short-term weather and belief in anthropogenic climate change. Weather, Climate, and Society 5(2):112-119. doi: 10.1175/WCAS-D-12-00048.1

Hamilton LC, Lemcke-Stampone M (2014) Arctic warming and your weather: Public belief in the connection. International Journal of Climatology 34:1723-1728. doi: 10.1002/joc.3796

Hamilton LC, Hartter J, Safford TG, Stevens FR (2014) Rural environmental concern: Effects of position, partisanship and place. Rural Sociology 79(2):257-281. doi: 10.1111/ruso.12023

Hamilton LC, Safford TG (2015) Environmental views from the coast: Public concern about local to global marine issues. Society and Natural Resources 28(1):57-74. doi: 10.1080/08941920.2014.933926

Hamilton LC, Hartter J, Lemcke-Stampone M, Moore DW, Safford TG (2015) Tracking public beliefs about anthropogenic climate change. PLOS ONE, doi: 10.1371/journal.pone.0138208

Halpert MS, Bell GD, Kousky VE, Ropelewski CF (1994) Fifth annual climate assessment 1993. Camp Springs, MD: Climate Analysis Center. Available at: http://www1.ncdc.noaa.gov/pub/data/cmb/bamssotc/climate-assessment-1993.pdf accessed 6/4/2015. 
Hart SJ, Schoennagel T, Veblen TT, Chapman TB (2015) Area burned in the western United States is unaffected by recent mountain pine beetle outbreaks. Proceedings of the National Academy of Sciences. doi:10.1073/pnas.1424037112

Hartter J, Stevens FR, Hamilton LC, Oester PT, Congalton RG, Ducey MJ, Crowley M (2014) Forest management and wildfire risks in inland Northwest. Durham, NH: Carsey Institute. Available at:

http://scholars.unh.edu/carsey/211/ accessed 6/5/2015.

Hartter J, Stevens FR, Hamilton LC, Congalton RG, Ducey MJ, Oester PT (2015) Modeling associations between public understanding, engagement and forest conditions in the Inland Northwest, USA. PLOS ONE. doi: 10.1371/journal.pone.0117975

Howe PD, Leiserowitz A (2013) Who remembers a hot summer or a cold winter? The asymmetric effect of beliefs about global warming on perceptions of local climate conditions in the U.S. Global Environmental Change 23(6):1488-1500. doi: 10.1016/j.gloenvcha.2013.09.014

IPCC (2013) Climate Change 2013: The Physical Science Basis. Contribution of Working Group I to the Fifth Assessment Report of the Intergovernmental Panel on Climate Change. Cambridge, UK: Cambridge University Press. doi: 10.1017/CBO9781107415324

Jones RE, Dunlap RE (1992) The social bases of environmental concern: Have they changed over time? Rural Sociology 57:28-47.

Jones EJ, Cerveny L, Nuss M, Seesholtz D (2015) Oregon's forest collaboratives: A rapid assessment. Oregon Forest Research Laboratory. Available at: http://hdl.handle.net/1957/55791 accessed 6/5/2015.

Kahan DM (2015) Climate science communication and the measurement problem. Advances in Political Psychology 36(1):1-43. doi: 10.1111/pops.12244

Kahan DM, Jenkins-Smith H, Braman D (2011) Cultural cognition of scientific consensus. Journal of Risk Research 14(2):147-174. doi: 10.1080/13669877.2010.511246

Kahan DM, Peters E, Wittlin M, Slovic P, Ouellette LL, Braman D, Mandel G (2012) The polarizing impact of science literacy and numeracy on perceived climate change risks. Nature Climate Change 2:732-735. doi:10.1038/nclimate1547

Kurz WA, Dymond CC, Stinson G, Rampley GJ, Neilson ET, Carroll AL, Ebata T, Safranyik L (2008) Mountain pine beetle and forest carbon feedback to climate change. Nature 452: 987-990. doi:

10.1038/nature06777

Langston N (1995) Forest Dreams, Forest Nightmares: The Paradox of Old Growth in the Inland West. Seattle: University of Washington Press. 
McCaffrey S, Toman E, Stidham M, Shindler B (2012) Social science research related to wildfire management: An overview of recent findings and future research needs. International Journal of Wildland Fire 22(1):15-24. doi: 10.1071/WF11115

McCright AM, Dunlap RE (2011) The politicization of climate change and polarization in the American public's views of global warming, 2001-2010. The Sociological Quarterly 52:155-194.

McCright AM, Dunlap RE, Xiao C (2014) The impacts of temperature anomalies and political orientation on perceived winter warming. Nature Climate Change. doi:

10.1038/NCLIMATE2443

McMillin JD, Fettig CJ (2007) Bark beetle responses to vegetation management treatments. Pp. 25-39 in in The Western Bark Beetle Research Group: A Unique collaboration with Forest Health Protection. US Department of Agriculture. Available at: www.fs.fed.us/pnw/pubs/pnw_gtr784.pdf accessed 6/5/2015.

Marquart-Pyatt ST, McCright AM, Dietz T, Dunlap RE (2014) Politics eclipses climate extremes for climate change perceptions. Global Environmental Change 29:246-257. doi:

10.1016/j.gloenvcha.2014.10.004

Menne MJ, Williams CN Jr, Vose RS (2009) The U.S. Historical Climatology Network monthly temperature data, version 2. Bulletin of the American Meteorological Society July:995-1007. doi: 10.1175/2008BAMS2613.1

Moritz MA, Batllori E, Bradstock RA, Gill AM, Handmer J, Hessburg PF, Leonard J, McCaffrey S, Odion DC, Schoennagel T, Syphard AD (2014) Learning to coexist with wildfire. Nature 515(6):58-66. doi:10.1038/nature13946

Myers TA, Maibach EW, Roser-Renouf C, Akerlof K, Leiserowitz AA (2013) The relationship between personal experience and belief in the reality of global warming. Nature Climate Change 3:343-347. doi:10.1038/nclimate1754

NASA (National Aeronautics and Space Administration) (2015) GISS surface temperature analysis. Goddard Institute for Space Studies. Available at: http://data.giss.nasa.gov/gistemp/ accessed 3/19/2015.

National Interagency Fire Center (2013) Federal firefighting costs (suppression only). Available at: http://www.nifc.gov/fireInfo/fireInfo_documents/SuppCosts.pdf accessed 12/4/2015.

NOAA (National Oceanic and Atmospheric Administration) (2015) U.S. Climate Divisions dataset nClimDiv. National Oceanic and Atmospheric Administration. Available at:

http://www.ncdc.noaa.gov/monitoring-references/maps/us-climate-divisions.php accessed 3/17/2015.

NRC (National Research Council) (2011) Climate Stabilization Targets: Emissions, Concentrations, and Impacts over Decades to Millennia. Washington DC: National Research Council, National Academies Press. 
Johnson K, Santos F (2015) Western wildfires consume manpower and acreage. New York Times, August 20. Available at http://www.nytimes.com/2015/08/21/us/3-firefighters-die-in-crash-on-way-towashington-state-blaze.html?_r=0 accessed 9/6/2015.

Overpeck JT, Rind D, Goldberg R (1990) Climate-induced changes in forest disturbance and vegetation. Nature 343:51-53.

Palmer WC (1965) Meteorological Drought. Research paper no.45, U.S. Department of Commerce Weather Bureau.

Peterson DL, Vose JM, Patel-Weynand T (eds) (2014) Climate Change and United States Forests. New York: Springer.

Qin H (2015) Comparing newer and longer-term residents' perceptions and actions in response to forest insect disturbance on Alaska's Kenai Peninsula: A longitudinal perspective. Journal of Rural Studies 39:51-62. doi:10.1016/j.jrurstud.2015.03.007

Sample VA, Bixler RP (eds) (2014) Forest Conservation and Management in the Anthropocene: Conference Proceedings. Fort Collins, CO: Rocky Mountain Research Station, Forest Service, US Department of Agriculture. Available at: http://www.fs.fed.us/rm/pubs/rmrs p071.html accessed $3 / 16 / 205$.

Shao, W (2015) Are actual weather and perceived weather the same? Understanding perceptions of local weather and their effects on risk perceptions of global warming. Journal of Risk Research. doi: $10.1080 / 13669877.2014 .1003956$

Shao W, Keim BD, Garland JC, Hamilton LC (2014) Weather, climate, and the economy: Explaining risk perceptions of global warming, 2001-2010. Weather, Climate, and Society 6(1):119-134. doi: 10.1175/WCAS-D-13-00029.1

Stavros EN, Abatzoglou JT, McKenzie D, Larkin NK (2014) Regional projections of the likelihood of very large wildland fires under a changing climate in the contiguous Western United States. Climatic Change 126(3-4):455-468. doi: 10.1007/s10584-014-1229-6

Taber CS, Lodge M (2006) Motivated skepticism in the evaluation of political beliefs. American Journal of Political Science 50(3):755-769.

Toman E, Shindler B (2003) Hazardous fuel reduction in the Blue Mountains: Public attitudes and opinions. USDA Forest Service Proceedings RMRS-P-29: 241-254. Available at: http://www.fs.fed.us/rm/pubs/rmrs_p029.pdf accessed 6/5/2015.

USDA (United States Department of Agriculture) (2015) Forest Service Chief Predicts "Above Normal" Wildland Fire Potential in Much of the West. News release May 5. Available at:

http://www.usda.gov/wps/portal/usda/usdamediafb?contentid=2015/05/0126.xml\&printable=true\&conten tidonly=true accessed 9/3/2015. 
USFS (United States Forest Service) (2015) The Rising Cost of Wildfire Operations: Effects on the Forest Service's Non-Fire Work. U.S. Department of Agriculture. Available at: http://www.fs.fed.us/aboutagency/budget-performance/cost-fire-operations accessed 9/3/2015.

USHCN (United States Historical Climatology Network) (2015) Long-term daily and monthly climate records from stations across the contiguous United States. Carbon Dioxide Information Analysis Center. Available at: http://cdiac.ornl.gov/epubs/ndp/ushon/ushcn_map_interface.html accessed 1/22/2016

Van Liere KD, Dunlap RE (1980) The social bases of environmental concern: A review of hypotheses, explanations and empirical evidence. Public Opinion Quarterly 44(2):181-197.

Weed AS, Bentz BJ, Ayres MP, Holmes TP (2015) Geographically variable response of Dendroctonus ponderosae to winter warming in the western United States. Landscape Ecology. doi: 10.1007/s10980015-0170-z

Wood BD, Vedlitz A (2007) Issue definition, information processing, and the politics of global warming. American Journal of Political Science 51(3):552-568. doi: 10.1111/j.1540-5907.2007.00267.x

Zaval L, Keenan EA, Johnson EJ, Weber EU (2014) How warm days increase belief in global warming. Nature Climate Change 4:143-147. doi: 10.1038/nclimate2093 